\title{
The Use of Funny Story in Teaching Reading
}

\author{
Brigitta Septarini Rahmasari
}

\author{
Universitas PGRI Madiun \\ *Corresponding author. Email: brigitta@unipma.ac.id
}

\begin{abstract}
Mastering reading skill needs learners' experiences. The experiences could be enriched by the motivation of the learners to read. It is believed a funny story is an interesting reading material that can help the learners achieve comprehension. The purposes of this research are to describe the procedures of teaching reading by using funny stories and to describe the students' responses to the use of funny stories in teaching reading. The research was qualitative. The data of this research were taken from the observation, interview, and questionnaire. Meanwhile, the techniques of data analysis are using data reduction, data display, and conclusion drawing. Based on the result of the research, it was found out that the researcher follows the procedures of teaching such as reading the funny stories in a loud voice, giving the clues to the difficult words, asking the students to do the exercises, then asking the students in groups to give their comments and judgments about the story. Meanwhile, the responses show that almost all students agree that funny stories could be used as reading material. The topics given to the students are interesting, and the students look enthusiastic in reading class. The implication is the use of funny stories could motivate the students to read and improve their comprehension.
\end{abstract}

Keywords: funny story, reading, motivation, comprehension

\section{INTRODUCTION}

In teaching reading, four skills have to be taught by the teacher. The competency-based curriculum state that those four skills are reading, listening, speaking, and writing that must be taught in harmony, but the main emphasis is on reading skill. It means reading has more proportions than listening, speaking and writing do. There are many reasons why getting students to read English texts is an important part of the teacher's job (Harmer, 1998)

First, the students want to be able to read texts in English either for their careers, for study purposes or simply for pleasure. Anything the teacher can do to make reading easier for the students must be a solution. Second, reading is important for other purposes too: any exposure to English ( provided students to understand it more or less ) is a good thing for language students. At the very least, some of the languages stick in their minds as part of the process of language acquisition, and if the reading text is especially attractive and engaging, the acquisition is likely to be even more successful. Third, reading text also provides opportunities to study language : vocabulary, grammar, punctuation, and the way students construct sentences, paragraphs and texts. Lastly, good reading texts can introduce interesting topics, stimulate discussion, excite imaginative responses and be the springboard for well-rounded, fascinating lessons.

Most of the students do not like reading in English, while others think reading is boring. It is caused by the teacher. The English teacher in the classroom usually asks the students to read textbooks such as science, technology, or politics. They do not understand the content of the material. The kind of material makes the students get bored, feel anxious and frustrated. Besides, there are still so many students who do not have enough vocabulary. It is also one of the factors that make them not like reading. If their teachers give those interesting reading materials, they are not bored easily and can comprehend what they read. Besides the teacher only does reading aloud with broad oral explanation and does not give chance for students to express their opinions. Also no effective teaching technique is used by teachers. Most of them use traditional and monotonous technique.

To avoid the students' boredom the researcher tries to use funny stories in teaching reading. The students enjoy something that can make them laugh. This kind of material is also able to increase their interest in reading, give them more new cultural information, new vocabulary, and more fun. Thus, they get a lot of vocabulary items from that reading material, and it can make them easier in understanding the English texts. 
Funny stories can be anecdotes. The term of anecdote which is in this learning material refers to the text that in Curriculum 2004 have the purpose to tell about unusual events and funny. As the English language Curriculum 2004 for Junior High School and Madrasah Tsanawiyah, anecdote text was learned in second grade. Kind of this text has become an important thing in daily life because it is easy to find in mass media and language textbooks. So, mastery of this text can also be used as a measuring rod of literature level. Funny is also called humour. Humour can easily be seen as a way of activating motivation and directing attention, but it can also be used in other events, from stimulating recall to enhancing retention to eliciting performance and providing feedback. Humour can help in breaking down the effective language acquisition and learning that can take place. Based on the formulation of the problem, the objectives of the research can be formulated as follows : to know procedures of teaching reading by using funny stories and to describe the students' responses to the use of funny stories in teaching reading.

\section{REVIEW OF RELATED THEORIES}

\subsection{The Function of Using Funny Stories In The Teaching of Reading}

A funny story has some function in the teaching learning process especially in reading. Muqun and $\mathrm{Lu}$ whose opinion was quoted by Hanvey in his article in Asian EFL journal ( $2006: 16$ ) argues for the use of English humor or funny story as an important element in EFL instruction. Funny stories can help students understand the inseparable link between language and culture and provide a means through which socio-cultural context of language can be better understood. Funny stories or humor story can also reduce the stress associated with learning a foreign language and promote integrative motivation to help students develop their own sense of humor and emotional intelligence. It means that introducing funny story or humor as early as possible in the learning process enhances not only the students' ability to learn the words, but also to understand their meaning within their cultural context.

Humor or funny story can be used as a way of activating motivation and directing attention, but it can be used in other events that happened in everyday from stimulating recall to eliciting performance. It can help in breaking down the effective barriers and increasing enthusiasm, so that more effective language acquisition and learning can take place. As Scott (1990) says," stimulating children's thinking and concept development, reading to the children stories that are humorous helps children to think about everyday events and concept and if the stories are humorous, the laughter generate helps the children to relax".
There are some benefits of using humorous or funny stories as a material for teaching reading comprehension : 1) Humorous or funny story is interesting. When students read a humorous or funny story, students are happy and enjoy the story, because the story can make them laugh. Reading a humorous or funny story makes students' feeling happy and increases their motivation to read more (Mendatu, 2008). Besides, the class will be also bright up and more interested in language lessons. 2) Humorous or funny story is entertaining. When students read a humorous or funny story the students may laugh or at least smile at the story. By laughing and smiling, we show that we are happy and entertained. So it can be said that humorous or funny story is entertaining. 3) Humorous or funny story is practical in the sense of thought when it gives a concept clearly of what a word may mean since it is much simpler and more vivid than a long explanation would be (Chik, 2005). In other words, humorous or funny story is easy to understand and the reader directly knows what is talking about, because it is simple. 4) Humorous or funny story is realistic. A humorous or funny story is realistic, because it uses the human act as the themes. There are many kinds of fields, such as social, economic, education, politic reflected in comedy performance (humorous in adental) (Chik, 2005). Alternatively, it can be said that humorous or funny take human

daily activity as them. 5) Humorous or funny story is flexible. If students want to read humorous or funny story, they do not have to prepare a quiet room like library to increase their concentration to the text (Chik, 2005). Students also do not have to choose the right time when the reading is begun. That is why humorous or funny story is flexible.

\subsection{Kinds of Reading}

Talking about reading there are two kinds of reading. Those are reading aloud and silent reading (Djiwandono, 2002)

\subsubsection{Reading Aloud}

Urquhart (1998) in the book entitled Practical Techniques for Language Teaching defined that" Reading aloud is a way of teaching pronunciation teachers must understand that texts should only be aloud which have been written to be read aloud". It is supported by Tarigan (1990) that people who read aloud must know the meaning of the text and have the speed eyes of reading to communicate ideas and feeling to other peoples. Soedarso (2004) further mention that there are the rules prepared or done by the teacher through reading aloud, as follows : At very low levels, the teacher reads, followed by the class reading orally sentence by sentence. For low levels, the class repeats orally after the tape ( more difficult that repeating after the teacher ). The 
teacher reads a paragraph, then the class reads the paragraph chorally possibly followed by an individual reading the same paragraph.

An individual reads sentence by sentence after the teacher.

Based on the statement above, it can be concluded that reading aloud is a useful technique in which it should be done individually or in small group. The teacher can use it as a means of training and checking rhythm and pronunciation. Besides, reading dialogues aloud in pairs or groups is an efficient way of checking work.

\subsubsection{Silent Reading}

Silent reading is the simplest technique of reading. Silent reading must be followed by questions to ensure that all the class really read and understand the appropriate section (Soedarso, 2004)

\subsubsection{Techniques of Reading}

According to March and Sharpe (2003), there are two techniques of reading, Those are scanning and skimming

\subsubsection{Scanning}

March and Sharpe (2003) say that scanning is a technique that gives a sense of main topics and ideas, gives clear picture of overall organization.

According to Soedarso (2004)," scanning is a technique of reading to get information without reading its whole". The kinds of scanning that is done in daily activities ( Soedarso, 2004) are :

\subsubsection{Scanning prose}

Scanning prose is looking for information from a certain topic in reading.

\subsubsection{Scanning the information of the certain topic}

In writing an article, a writer needs a lot of references. A writer also needs to learn the topic that will be discussed from the kind of source, collecting the matter about the certain topic, a writer unnecessary to read them all of the book parts. But it is enough by scanning to the table of content, index or paragraph (Soedarso, 2004)

\subsubsection{Scanning the word in the dictionary}

Looking at a word in the dictionary is done through scanning. This is intended to find it fast ( Soedarso, 2004)

Scanning the TV program
In the TV program, the reader need scanning that be found in a monitor so that the reader can choose TV program based on desire of the reader ( Soedarso, 2004)

Based on the statement above, scanning is a technique of reading that gives a sense of main topics or ideas by searching a specific piece of information without reading its whole. The kinds of scanning that are done in daily activities are : scanning prose, scanning the information of a certain topic, scanning the word in the dictionary and scanning the TV program.

\subsubsection{Skimming}

Skimming is the reading technique that aims at selectively reading the material to search for detailed information and to survey for general ideas when the readers are not responsible for specific comprehension, to save time, to get an overall view, and to determine if readers need to read in deep ( March and Sharpe, 2003). It is supported by Soedarso (2004) that skimming is the action to take the main idea from the reading or skimming means looking for the important case from a reading, such as : the main idea and details and the goals of skimming as follows :

to recognize the topic of reading, to know opinions from other people,to get important parts that we need without reading the whole, to know the organization of the writing from the reading, to warm up has been read (Soedarso, 2004)

Hence, skimming is the technique that purposes selectively read the material to find or take specific information for detailed comprehension and goals of skimming are to recognize the topic of reading, to know opinions from other people and to know the organization of the writing from the reading.

\section{METHODOLOGY}

\subsection{Research Design}

This research would focus mainly on the process of teaching and learning English, especially reading skills that happened in the classroom. In line with this purpose, the appropriate researcher design is a qualitative study because the data is non-numerical form. It is in line with Sukardi (2006)," the qualitative data which are recorded in non-numerical forms such as transcripts of classroom interactions".

Based on the statement above, it can be concluded that descriptive qualitative research is method of research which interprets the information from viewpoint kinds of subject or objects, ideas or events that happened in the classroom and the data which are recorded in nonnumerical forms. The researcher obtained the data by using questionnaires and interviews. The circumstances was described in detail because everything had an 
important point of becoming the clue to open a more comprehensive understanding on what happened in the class. After the information was able to find out the research questions then the research came to end.

\subsection{Data Collection Technique}

\subsubsection{Observation}

Observation is one technique in collecting data. Observation is systematic and recording of phenomena that are observed. Gulo (2002) states that observation as monitoring and voting systematically for indications faced an object of research. Observation is also has meant as a tool or way to collect the data which is done systematically and coincidentally. While, Hadari (2005) states, "observation is collecting information involves watching and listening to events then recording what occurred". It means that observation is the way to research directly by watching and listening the object the records what happened in the events.

In this research, observation is conducted when the funny story is applied in the reading class

\subsubsection{Interview}

Interview is technique used in collecting the data. Interview is a technique of collecting data to communicate between researcher and respondent or subject directly. Cholid (1999) states "Interview is a means of gathering information by asking a number of question to be answered orally as well". It means that interview is a tool to collect information by asking some questions by researcher to the respondent orally and the respondent answers some questions of the researcher orally and as well.

\subsubsection{Questionnaire}

There are two kinds of questionnaire, those are an open questionnaire and closed questionnaire. An open questionnaire gives the opportunity to the respondent to answer with their answer or sentence and for a close questionnaire, the researcher gives answer in multiple choice form then the respondent must answer one of them, so the respondent do not have opportunity with other answers (Arikunto, 2002 ).

Based on the statement above, it can be concluded that questionnaire method is a list including the sequence of questions related to the problem or field that will be examined or it will give the written questions that must be answered by respondent and there are two kinds of questionnaire, those are an open questionnaire and close questionnaire. The researcher chooses a close question type ( multiple choice form ).

\subsubsection{Data Analysis}

All the data collected in the observation, interview, and questionnaire are analyzed. The specific steps of the data analyses were :

The data obtained from classroom observation were analyzed by using descriptive analysis. By making the description during the classroom activities in teaching learning process (the activities done by the teacher and students) the analysis was done

The data collected through interview were used to support the data obtained through observation.

The data obtained from questionnaire were also analyzed by using technique of descriptive qualitative.

The last step, the researcher described the data by classifying them based on the problems of study.

\section{RESEARCH FINDING}

\subsection{Research Finding}

\subsubsection{The procedures of the use of funny stories in teaching reading}

a) When the teacher started teaching reading, she directly gave questions to the students. She did it to motivate them to understand the topic. She gave some questions that lead the students to understand the topic that was going to be discussed. For Example:

Teacher : Ok students, please attention and look at the title. What is the title of the text?

Student 13 : A Big Dinner Party.

Teacher : Good. So what the meaning of party? Student 14 : Pesta.

Teacher : Good. And then what is the meaning of dinner?

Student 15 : Makan malam.

Teacher : Right. Have you ever go to a party?

Students : ( Some say Yes and some say No )

Teacher : ok

b) Before the students read the anecdote/funny Story, the teacher asked them to read the questions related to the text first.

2). In while-reading activity

a) The teacher asked the students to read aloud.

b) The teacher gave true or false questions hoping that the students would got the detail information from the story. The students did the exercises individually to give the reasons and argumentation why they choose that answer. When they had finished doing exercises, the teacher then discussed the answers with them. For example: 
Teacher : For question number 1 , is it true or false " Nasreddin had two nice fat sheep?". Raise your hand!

Student 2 : It is Mom.

Teacher : Good. Why do you answer false? Please give the reason.

Student 2 : I answer false because in the first line said that Nasreddin has a nice fat sheep. It is appear in the sentence "One day, the boys of Nasreddin's village said to him, "You have a nice fat sheep".

Teacher : Ok, good answer.

c) The teacher allowed all the students to read the story silently and to underline the difficult words that they found in this activity. As usual, they could open the dictionary to find the meaning of those words that they found on the text by technique of scanning.

d) The students were asked to choose words that have same meaning in the text and did the exercises individually. Some of the student still found difficulty in doing this activity and they discussed with their friends the meaning of the words. They did their task seriously.

$$
\text { 1. Po }
$$$$
\text { st Activity }
$$

In this activity, the students review and evaluate the material. The researcher gave conclusion and asked the feeling of the students. They feel happy and enjoy when using funny story in reading class.

\subsubsection{The student's responses to the use of funny story in teaching reading}

\subsubsection{Result of interview}

Based on the result of the interview from the English teacher, the researcher gets the data as follows:

a. The students are very enjoyable and enthusiastic to follow the teaching learning process in reading class by using funny stories.

b. The roles and responsibilities of the students in English teaching is good enough. The teacher uses Funny Stories as the material for teaching reading and the students are more interested and active.

c. The students are being noisy when they discuss the material presented by the teacher.

d. Many of the students do not bring the dictionary, so the teacher is difficult for applying technique of scanning.

e. The students are more active and enjoy reading class. They also get new vocabularies

\subsubsection{Result of questionaire}

The questionnaire given to the students was meant to answer the second statement of the problem that was to find out the students' responses in reading class using funny stories. The researcher set closed-question type that include some possible answer

Based on the data of questionnaire, the researcher found out the information, as follows:

The Students' Opinion about the procedures of Using Funny Stories in Teaching Reading

From the students' responses, as for the application of the of using Funny Stories in reading class, $63.16 \%$ of the students agreed that it was easily understood and $21.05 \%$ stated that it was rather difficult. Only $5.26 \%$ of the students stated that it was very easy.

Technique when Funny Stories applied in reading class, none of them thought that they did not like them. Almost $55.26 \%$ of the students' opinion were they like them and $31.58 \%$ of the students like them very much.

About the language and sentences that is used in the story, as we could see $60.53 \%$ of the students stated that the language and sentences were rather difficult, and the others stated ( $26.32 \%$ ) that Funny Stories were easy to understand. About $55.26 \%$ of the students stated they often found difficult words.

To overcome their problem, $42.11 \%$ of the students stated that they often opened dictionary to find the meaning of the difficult words, and read three or more times to understand the text.

The Students' Opinion about the Topics of Materials

About the topics of the implementation of Funny Stories, as we could $55.26 \%$ of the students stated that the topics were interesting even $34.21 \%$ of them stated that they were very interesting. During the application of the topics, $47.37 \%$ the students were enthusiastic in the reading class, $23.68 \%$ were very enthusiastic, and no one was not enthusiastic in the reading class.

\section{The Teacher's Role}

From the result of questionnaire, it showed that almost all students very often asked the teacher when they did not understand the text, and the teacher always answered the students' questions.

As for the students' mistakes, most students agreed that the teacher often corrected their pronunciation mistakes. Furthermore, $89.47 \%$ of the students said that the teacher supported them to participate actively in the reading class. During the applications of the technique, $63.16 \%$ of the students stated that the teacher rather dominated the reading class 


\section{DISCUSSION}

Based on the observation and interview, the researcher could see that the teacher followed the stages in teaching reading, namely pre-reading, while-reading, and post-reading activities.

The researcher could see that in pre-reading activities the reseacher greets the students, checks attendance list, and give brainstorming. Those series of pre-activities are supported by Mason (2007). Those series can stimulate and motivate students to get ready for the main activity.

In while-reading activities, the teacher always read the text in a loud voice and asked the students to read it. And then the teacher asked the students to do the exercises. It was done to know how far the students understand the text. In this case, the researcher used the technique of skimming to find the main idea of the text. The researcher discovers that the series of those main activities are relevant to previous research from Situmerang (2018) such as asking the student to read the text and do the exercises. However there are some differences found by the researcher. The first difference is the type of text. Situmerang (2018) uses narrative text with the combine in humor series in his research meanwhile in this research, the researcher uses anecdote. The second difference is the way students do the exercises. In previous research, Situmerang (2018) asks the students to do the exercises in the group while the researcher asks the students to do the exercises individually.

In the post activity, there are a series of activities that are relevant to lesson plan and previous research. They are reviewing and making a conclusion. through the funny story, students can feel fun and enjoy during the class

Based on the data of the questionnaire and interview, the researcher found out that the topics that the teacher gave to the students were interesting and the students look enthusiastic and enjoy the reading class. It is supported by the fact that almost $80 \%$ of the students state that the topics are interesting. Funny Stories help them to understand the reading text easily and make them not bored in reading. The students state that they are motivated because funny story gives them fun. It is in line with the statement of Chik (2005) that humor story can help in making learning experience more pleasurable.

The students participate actively in class. Almost all of the students agree that the use of funny stories could motivate them to read and they realize that their ability to read was improved.

Another support is proposed by Meyer (2006). He says that emotional energy is released by humor story and it acts as a positive motivation towards the reading and humor strengthen memory and increase reading comprehension.
It is also supported by the research finding from Tang (2019) entitled the humor story in teaching reading comprehension. The result of the research showed that there was significant difference between the students' scores after they were taught by using humor story and before it. It was proven by the mean score of post test was higher than the mean score of pretest $(57.57>40.33)$

Meanwhile, based on the research conducted by Situmerang (2018) entitled improving students' reading comprehension by using humor stories in grade eight of SMPN 5 sibolga in academic year 2017/2018. The result shows that the students' reading comprehension improves from cycle 1 until cycle 2 . In precycle, the average of students score is 48.88 , in cycle 1 the average of students score is 64.58 and in the cycle 2 of the students score is 78.88. Also, the students' interest in reading comprehension increased because they could share their knowledge and their opinion with each other and also find the definition of difficult words together.

\section{CONCLUSIONS}

Funny stories can be used or applied in teaching reading for the second grade students of junior high school. This kind of reading text can increase the students' interest in reading, give them more new cultural information, more new vocabulary, and more fun. The students' responses to funny stories are good. The use of funny stories in teaching reading is very useful. Further studies can be done and built on classroom action research so that the researcher can revise the weaknesses of this study

\section{AUTHORS' CONTRIBUTIONS}

The author contributed to the design and implementation of the research, to the analysis of the results and to the writing of the manuscript.

\section{ACKNOWLEDGMENTS}

We thank Dr. Rosita Ambarwati, Dr. Lulus Irawati dan Dr. Sumani for useful discussion and comments on the manuscript. We also thank all students and teachers of SMPN 5 Madiun for support.

\section{REFERENCES}

[1]. Arikunto Suharsimi 1992. Prosedur Penelitian : Suatu Pendekatan Praktek. Jakarta : Rineka Cipta.

[2]. Chik, P. 2005. Humor and reading motivation in hongkong elementary school children. Proceeding of international conference on imagination and education

[3]. Cholid Narbuko \& Abu Achmadi. 1999. Metodologi Penelitian. Jakarta : Bumi Aksara. 
[4]. Djiwandono, P.Istiarto. 2002. Strategi Membaca Bahasa Inggris. Jakarta : Gramedia Pustaka Utama.

[5]. Gulo, W. 2002. Metodologi Penelitian. Jakarta : Gramedia Widiasarana Indonesia.

[6]. Hadari Nawawi. 2005. Metode Penelitian Bidang Sosial. Yogyakarta : IKAPI.

[7]. Harmer, Jeremy. 1998. How to Teach English : AN Introduction to be Practice of English Language Teaching. New York : Longman.

[8]. March, Janet \& Sharpe, Shally. 2003. Learning to Learn. Australia : Hawker Bronlow Education

[9]. Mason, J. 2002. Qualitative research. London: SAGE Publication .Ltd

[10]. Mendatu, Achmanto. 2008. Mengasah Sense of Humor. Yogyakarta : Media Pressindo.

[11]. Meyer, J.C. 2006. Humor as a double edged sword; Four Function of humor in communcation theory

[12]. Muqun, Wang \& Lu, Wang. 2006. The Function of Humor in Classroom Instruction. ASIAN EFL journal (online), volume 16, article 2.
[13]. Nunan, David. 2000. Research Methods in Language Learning. United Kingdom : Cambridge University Press

[14]. Scott, Wendy A \& Ytreberg, L.H. 1990. Teaching English to Children. New York: Longman.

[15]. Soedarso. 2004. Speed Reading: Sistem Membaca Cepat dan Efektif. Jakarta : Gramedia Pustaka Utama.

[16]. Sukardi, MS. 2006. Penelitian KualitatifNaturalistik: Dalam Pendidikan. Usaha Keluarga.

[17]. Tarigan, Henry G. 1990. Membaca Sebagai Suatu Keterampilan Berbahasa. Bandung : Angkasa.

[18]. Urquhart, A.H.\& Weir, C.J.1998. Reading in a second language. London and New York : Longman.

[19]. Situmeang, Lamhot martua. 2018. Improving students reading comprehension by using humor stories in grade eight of SMP N 5 Sibolga in academic year 2017/2018. Tapanuli journals vol 1 no 1 august 2018 ISSN 2622-8823

[20]. Tang Syamsu. 2019. The humor story in teaching reading comprehension. Journal of advanced english studies, vol 2 no 2 